\title{
Establishing Hard Fescue from Sod
}

\author{
M. Ali Harivandi, ${ }^{1}$ \\ William L. Hagan, ${ }^{2}$ \\ M. Zak Mousli, ${ }^{3}$ and $\mathrm{Lin} \mathrm{Wu}^{4}$
}

Additional IndeX wORds. Festuca longifolia, sod thickness, nonmowed turfgrass, groundcover, erosion

Summary. Stand establishment of direct-seeded hard fescue (Festuca longifolia) is slow. Sodding could speed establishment in landscape plantings. This study looked at the effects of two sod thicknesses and different rates of nitrogen fertilization before and after sodding, on stand establishment and overall turf quality. Evaluations 2, 4 and 8 weeks after sodding assessed rooting and overall turf quality. Thicker sod showed better rooting 4 weeks after planting; after 8 weeks, rooting of both thicknesses was similar. Nitrogen fertilization before or after sodding did not affect rooting. More nitrogen led to better overall turf quality up to 4 weeks after planting; however, this quality difference disappeared 8 weeks after sodding.

$\mathrm{H}$ ard fescue (previously F. ovina var. duriuscula), a native of Europe, is a medium-tall, semi-erect, long-lived, densely tufted, noncreeping bunch-type grass (Hitchcock, 1935). The plant is a heavy root producer with a high root-to-shoot ratio (Hafenrichter et al., 1979). Its extensive root system draws water from deep within the soil profile; this characteristic contributes to the grass's relatively high drought resistance. In addition, a heavy root system, abundant, dense leaves and a low crown make nonmowed hard fescue an excellent grass for erosion control (Thornburg, 1982).

This research was supported by Northern Calif. Turf and Landscape Council and Golf Course Superintendents Association of Northern Calif.. We thank the Grass Farm Sod Company, Morgan Hill, Calif., for supplying sod used in this study.

${ }^{1}$ Environmental horticulturist, University of Calif. Cooperative Extension, 1131 Harbor Bay parkway, No. 131, Alameda, CA 94502

${ }^{2}$ Research Associate, University of Calif. Cooperative Extension, 1131 Harbor Bay parkway, No. 131, Alameda, CA 94502.

${ }^{3}$ Formerly Superintendent, University of Calif. Bay Area Research and Extension Center, Santa Clara, CA 95050.

${ }^{4}$ Professor, Dept. of Env. Hort.,Univ. of Calif., Davis, CA, 95616.
Although hard fescue may be mowed, mowing is not recommended in areas with hot summers (Beard, 1973; Harivandi and Elmore, 1990). Nonmowed hard fescue, 8 to 16 inches $(20.3$ to $40.6 \mathrm{~cm})$ tall, is an attractive ground cover with a natural, meadowlike appearance (Harivandi and $\mathrm{Wu}$, 1990). This, along with adaptation to a wide range of soil conditions and low fertility requirements, qualifies it as a minimum maintenance nonmowed grass groundcover (Hafenrichter etal., 1979).

When hard fescue is direct-seeded, slow germination and seedling emergence retard stand establishment (Hafenrichter et al., 1979). This delayed stand development makes direct-seeded hard fescue impractical in cases where quick cover is needed or when weed invasion is anticipated. Sodding could bypass this limitation of hard fescue use; however, data on hard fescue sod production and sod rooting characteristics are limited.

The objectives of this study were to 1 ) determine if thick sod rooted and established faster than thin sod, and 2 ) if different rates of nitrogen fertilization before and after sod was laid enhanced sod establishment, overall turf quality and biomass production of a nonmowed hard fescue stand.

\section{Materials and methods}

Sod used in this study was produced at Grass Farm, Morgan Hill, Calif. on a clay loam soil. A mixture of equal parts 'Nordic' and 'Aurora' hard fescues was seeded at $130 \mathrm{lb} /$ acre (145.7 kg.ha-1) on 15 Aug. 1996. Ammonium sulfate was applied as needed based on visual evaluation of turf color, at a total annual rate of $174 \mathrm{lb} /$ acre $\left(195.0 \mathrm{~kg} \cdot \mathrm{ha}^{-1}\right)$. Sod was irrigated as needed to prevent stress. Overall, hard fescue exhibited uniform seed germination and seedling vigor and satisfactory coverage after seeding at the sod farm. The Grass Farm is located in the transitional zone: mild climate and no frost. Hard fescue grew to a height of 2 inches $(5.1 \mathrm{~cm})$ more rapidly than expected; however, thereafter growth slowed. About 9 months were required between seeding and sod harvest.

Although sod was ready 9 months after seeding, it was harvested at 14 months on 1 Oct. 1997, due to unavailability of the test site. It was harvested as 0.75 -inch-thick $(1.905-\mathrm{cm})$ and 1.5-inch-thick $(3.81-\mathrm{cm}) 1$-yard ${ }^{2}$ $\left(0.84-\mathrm{m}^{2}\right)$ slabs, using a standard twoperson sod harvester.

This study began 2 Oct. 1997, at the University of Calif. Bay Area Research and Extension Center, Santa Clara, Calif. Site preparation consisted of roto-tilling the Campbell silty clay soil to 4 inches $(10.2 \mathrm{~cm})$ depth, then grading it. No soil amendment was applied. Experimental design was a $2 \times 2$ $\times 2$ factorial arranged in a randomized complete block in three replications. Plot size was $8 \times 6.5 \mathrm{ft}(2.4 \times 1.98$ $\mathrm{m})$. Variables included sod thickness (sod was harvested at 0.75 inch and 1.5 inches soil thickness) as main plots, fertilizer placement (soil surface or sod surface) as split-plots, and nitrogen rate $\left[0.5 \mathrm{lb} / 1000 \mathrm{ft}^{2}\left(24.4 \mathrm{l} \mathrm{kg} \cdot \mathrm{ha}^{-1}\right)\right.$ and $1 \mathrm{lb} / 1000 \mathrm{ft}^{2}\left(48.8 \mathrm{~kg} \cdot \mathrm{ha}^{-1}\right)$ of nitrogen from ammonium sulfate $(20 \mathrm{~N}-0 \mathrm{P}-0 \mathrm{~K})]$ as split-split-plots. All plots were in full sun and were irrigated thoroughly immediately after sod was laid, and regularly thereafter to prevent stress. All plots were mowed to a uniform height of 3 inches (7.6 $\mathrm{cm}) 2$ weeks after sodding, then not mowed again. Sod rooting and overall turf quality (as described below) were evaluated at 2,4 , and 8 weeks after sodding; biomass was measured 6 months after sodding.

To simulate standard practice in the landscaping industry, a grasp-andpull method was used to evaluate sod rooting strength (i.e., knitting). Sod was grasped with both hands and pulled up once quickly to determine how easily it separated from the soil surface as a function of rooting. A rating of 1 through 9 was used to evaluate rooting, based on the ease of pull and the extent of sod separation from the soil. A rating of 1 , indicating that sod did not root (knit) into the sodbed at all, was given when sod lifted easily from the soil. The highest rating, 9, applied when sod could not be separated from the sodbed, regardless of the pull that was applied, (on a percentage basis, we used the following scale: $1=0 \%$ rooting, $3=25 \%, 5=50 \%, 7=75 \%$, $9=100 \%)$. Ratings of three random spots per plot were averaged. A single individual made all sod rooting evaluations, waiting $\approx 5$ min between each plot.

To describe plot overall turf quality and appearance, the turf score (a system based on visual scores from 1 to 9) was used. On a scale of 1 to 9 , 9 represented most desirable appear- 
Table 1. F values for the analysis of variance of each measured characteristic of the hard fescue sod rooting study in Santa Clara, Calif., 1997.

\begin{tabular}{|c|c|c|c|c|c|c|c|c|c|}
\hline \multirow[b]{2}{*}{ Source } & \multirow[b]{2}{*}{ df } & \multicolumn{3}{|c|}{ Sod rooting ${ }^{\mathrm{z}}$} & \multicolumn{3}{|c|}{ Turf quality ${ }^{z}$} & \multicolumn{2}{|c|}{ Biomass $^{\mathrm{z}}$} \\
\hline & & 2 weeks & 4 weeks & 8 weeks & 2 weeks & 4 weeks & 8 weeks & Fresh & Dry \\
\hline Replication & 2 & 0.73 & 1.53 & --- & 0.51 & 3.00 & 2.71 & 15.97 & 19.52 \\
\hline $\mathrm{N}$ placement & 1 & 1.18 & 0.02 & --- & 3.06 & $30.25^{* *}$ & 1.56 & 0.14 & 0.15 \\
\hline \multicolumn{10}{|c|}{ Sod thickness $\times$} \\
\hline $\mathrm{N}$ placemen & 1 & 4.13 & 4.70 & --- & 0.06 & 6.25 & 0.87 & 0.10 & 0.14 \\
\hline $\mathrm{N}$ rate & 1 & 1.38 & 0.40 & --- & 1.50 & 0.14 & 0.18 & 0.22 & 0.22 \\
\hline \multicolumn{10}{|l|}{$\mathrm{N}$ placement $\times$} \\
\hline $\mathrm{N}$ rate & 1 & 0.52 & 0.19 & --- & 4.20 & 1.29 & 0.73 & 0.01 & 0.01 \\
\hline $\begin{array}{l}\text { Sod thickness } \\
\mathrm{N} \text { placemen }\end{array}$ & & & & & & & & & \\
\hline
\end{tabular}

Table 2. Mean hard fescue sod rooting observed at 2, 4, and 8 weeks after sodding with thin $(0.75 \text { inch thick })^{\mathrm{z}}$ and thick ( 1.5 inches thick) sod, in Santa Clara, Calif., 1997. Plots were fertilized with 0.5 and $1 \mathrm{lb} / 1000 \mathrm{ft}^{2 \mathrm{y}}$ nitrogen $(\mathrm{N})$ before and after sodding. The rating scale was 1 to 9 , with 9 being most rooted using grasp-and-pull method.

\begin{tabular}{lccc}
\hline & \multicolumn{3}{c}{ Weeks after sodding } \\
\cline { 2 - 4 } Treatment & $\mathbf{2}$ & $\mathbf{4}$ & $\mathbf{8}$ \\
\hline Sod thickness 0.75 inch & $5.4 \mathrm{a}^{\mathrm{x}}$ & $7.3 \mathrm{a}$ & $9.0 \mathrm{a}$ \\
Sod thickness1.5 inches & $7.4 \mathrm{a}$ & $8.3 \mathrm{~b}$ & $9.0 \mathrm{a}$ \\
LSD 5\%w & 3.9 & 0.9 & --- \\
$\mathrm{N}$ before & $6.7 \mathrm{a}$ & $7.9 \mathrm{a}$ & $9.0 \mathrm{a}$ \\
$\mathrm{N}$ after & $6.1 \mathrm{a}$ & $7.8 \mathrm{a}$ & $9.0 \mathrm{a}$ \\
LSD 5\% & 1.6 & 1.2 & --- \\
$\mathrm{N}$ at $0.5 \mathrm{lb} / 1000 \mathrm{ft}^{2}$ & $6.3 \mathrm{a}$ & $7.9 \mathrm{a}$ & $9.0 \mathrm{a}$ \\
$\mathrm{N}$ at $1 \mathrm{lb} / 1000 \mathrm{ft}^{2}$ & $6.6 \mathrm{a}$ & $7.8 \mathrm{a}$ & $9.0 \mathrm{a}$ \\
LSD 5\% & 1.2 & 0.6 & --- \\
\hline
\end{tabular}

${ }^{\mathrm{z}} \mathrm{l}$ inch $=2.54 \mathrm{~cm}$.

y $1 \mathrm{lb} / 1000 \mathrm{ft}^{2}=48.8 \mathrm{~kg} \cdot \mathrm{ha}^{-1}$

${ }^{x}$ Means in columns within main effects followed by the same letter are not significantly different at the $5 \%$ level. ${ }^{\mathrm{w}} \mathrm{LSD}=$ least significant difference.

Table 3. Mean overall turf quality ratings ( 1 to 9,9 best) of hard fescue observed at 2,4 , and 8 weeks after sodding with thin $(0.75 \text { inch thick })^{\mathrm{z}}$ and thick (1.5 inches thick) sod in Santa Clara, Calif., 1997. Plots were fertilized with 0.5 and $1 \mathrm{lb} / 1000 \mathrm{ft}^{2 \mathrm{y}}$ nitrogen $(\mathrm{N})$ before and after sodding.

\begin{tabular}{llcc}
\hline & \multicolumn{3}{c}{ Weeks after sodding } \\
\cline { 2 - 4 } Treatment & $\mathbf{2}$ & $\mathbf{4}$ & $\mathbf{8}$ \\
\hline Sod thickness 0.75 inch & $5.8 \mathrm{a}^{\mathrm{x}}$ & $6.1 \mathrm{a}$ & $5.8 \mathrm{a}$ \\
Sod thickness 1.5 inches & $5.7 \mathrm{a}$ & $5.7 \mathrm{a}$ & $5.6 \mathrm{a}$ \\
LSD 5\%w & 2.1 & 2.0 & 2.5 \\
$\mathrm{~N}$ before & $5.4 \mathrm{a}$ & $5.4 \mathrm{a}$ & $5.3 \mathrm{a}$ \\
$\mathrm{N}$ after & $6.0 \mathrm{a}$ & $6.3 \mathrm{~b}$ & $6.0 \mathrm{a}$ \\
LSD 5\% & 0.9 & 0.4 & 1.5 \\
$\mathrm{~N}$ at 0.5 lb/1000 ft & $5.4 \mathrm{a}$ & $5.5 \mathrm{a}$ & $5.5 \mathrm{a}$ \\
$\mathrm{N}$ at $\mathrm{lb} / 1000 \mathrm{ft}^{2}$ & $6.0 \mathrm{~b}$ & $6.3 \mathrm{~b}$ & $5.8 \mathrm{a}$ \\
LSD 5\% & 0.4 & 0.5 & 0.9 \\
\hline
\end{tabular}

${ }^{\mathrm{z}} 1 \mathrm{inch}=2.54 \mathrm{~cm}$.

l l lb $/ 1000 \mathrm{ft}^{2}=48.8 \mathrm{~kg} \cdot \mathrm{ha}^{-1}$.

${ }^{\mathrm{x}}$ Means in columns within main effects followed by the same letter are not significantly different at the $5 \%$ level. ${ }^{\mathrm{w}} \mathrm{LSD}=$ least significant difference. ance and best quality turf. A rating of 1 represented a completely dead sward. Ratings of 6 and higher represented acceptable turf.

Six months after sodding, a cylinder 2 inches high and 10 inches $(25.4$ $\mathrm{cm})$ in diameter was used to harvest biomass from two randomly selected spots in each plot. The cylinder was pushed onto the turf stand until its lower edge came in contact with the soil surface. Then, biomass extending above the cylinder's upper rim was clipped, weighed, and averaged for the two samples per plot. Both fresh and dry weight [oven dried for $48 \mathrm{~h}$ at $\left.100^{\circ} \mathrm{F}\left(37.8^{\circ} \mathrm{C}\right)\right]$ were recorded.

Statistical analyses, indicating main effects and interactions, appear in Table 1.

\section{Results and discussion}

Table 2 presents the effects of various treatments on sod rooting 2,4 , and 8 weeks after sod was laid. Thick sod (cut at 1.5 inches) had rooted better than thin sod (cut at 0.75 inch) 4 weeks after being laid. Eight weeks after sodding, however, sod-rooting was the same for both sod thicknesses. The amount of nitrogen applied, or the placement of fertilizer (on soil or on sod) at the time of sodding, had no effect on sod rooting (Table 2). These results suggest that where rapid establishment (less than 4 weeks) is desired, a thicker cut hard fescue sod is preferable to a thin cut. Well-knitted sod could be expected within 4 weeks, when starting with sod cut 1.5 inches thick, while full sod knitting may take up to 8 weeks if 0.75 - 
Table 4. Mean fresh and dry biomass produced by hard fescue sod 6 months after sodding with thin $(0.75 \text { inch thick })^{\mathrm{z}}$ and thick ( 1.5 inches thick) sod, in Santa Clara, Calif., 1997. Plots were fertilized before and after sodding with 0.5 and 1 $1 \mathrm{~b} / 1000 \mathrm{ft}^{2 \mathrm{y}}$ nitrogen $(\mathrm{N})$.

\begin{tabular}{|c|c|c|}
\hline \multirow[b]{2}{*}{ Treatments } & \multicolumn{2}{|c|}{ Biomass $(\mathrm{lb} / \mathrm{acre})^{\mathrm{x}}$} \\
\hline & Fresh & Dry \\
\hline Sod thickness 0.75 inch & $1586 a^{w}$ & $566 \mathrm{a}$ \\
\hline Sod thickness 1.5 inches & $1660 \mathrm{a}$ & $627 \mathrm{a}$ \\
\hline LSD $5 \% \mathrm{v}$ & 679 & 209 \\
\hline $\mathrm{N}$ before & $1686 \mathrm{a}$ & $619 a$ \\
\hline $\mathrm{N}$ after & 1559 a & $575 \mathrm{a}$ \\
\hline LSD $5 \%$ & 919 & 331 \\
\hline $\mathrm{N}$ at $0.5 \mathrm{lb} / 1000 \mathrm{ft}^{2}$ & 1511 a & $566 \mathrm{a}$ \\
\hline $\mathrm{N}$ at $1 \mathrm{lb} / 1000 \mathrm{ft}^{2}$ & $1729 a$ & $636 \mathrm{a}$ \\
\hline LSD $5 \%$ & 740 & 262 \\
\hline
\end{tabular}

${ }^{2} 1$ inch $=2.54 \mathrm{~cm}$.

y $1 \mathrm{lb} / 1000 \mathrm{ft}^{2}=48.8 \mathrm{~kg} \cdot \mathrm{ha}^{-1}$.

${ }^{x} \mathrm{l} \mathrm{lb} /$ acre $=1.12 \mathrm{~kg} \cdot \mathrm{ha}^{-1}$.

"Means in columns within main effects followed by the same letter are not significantly different at the $5 \%$ level.

${ }^{v_{L S D}}=$ least significant difference.

inch sod is used. The grasp-and-pull evaluation method used in this study, though crude, reflects common field conditions and was able to detect significant rooting differences at 4 weeks between thick (8.34) and thin (7.30) sod, and revealed full rooting of both sod thickness at 8 weeks.

Table 3 presents the nitrogen treatment effects on turf quality. The higher nitrogen fertilization rate $(1 \mathrm{lb} /$ $1000 \mathrm{ft}^{2}$ ) produced higher quality turf than the lower $\left(0.5 \mathrm{lb} / 1000 \mathrm{ft}^{2}\right)$ rate up to 4 weeks after sodding. Eight weeks after sodding, however, the difference in quality due to nitrogen fertilization disappeared. Additionally, application of fertilizer on sod after it was laid produced a higher quality turf up to 4 weeks after sodding than application of fertilizer on the sodbed. By the 8th week after sodding, this difference also disappeared. These results suggest that sod quality is greater the first 4 weeks with nitrogen application rate of $1 \mathrm{lb} /$ $1000 \mathrm{ft}^{2}$, applied over the top compared to the lower nitrogen rate or applied on soil before sod is laid.
Table 4 reports the effect of treatments on fresh and dry biomass production 6 months after sodding. As shown, none of the treatments affected biomass production. It is interesting to note that hard fescue produced large amounts of biomass (a function of growth and tillering), even with no supplemental fertilizer for 6 months. This is an important characteristic of hard fescue when used as a nonmowed turfand low-maintenance ground cover, especially because it is often planted on relatively infertile cut/fill slopes or other sites for erosion control.

\section{Conclusions}

This study demonstrates that hard fescue sod production is culturally feasible and leads to rapid stand establishment when transplanted. The main obstacle to sod production is the relatively long growing period: hard fescue sod requires $\approx 9$ months before it is ready for harvest. Other cool-season grasses, like tall fescue (Festuca arundinacea), which are ready for market as sod in less than half the time, will be more economical for growers unless demand for hard fescue sod is sufficiently great to justify higher prices or greater sales volume.

Long production time notwithstanding, hard fescue sod can be rapidly established (within 1 month) in the landscape. Because hard fescue remains the choice of landscapers looking for low maintenance turf, rapid sod establishment, requiring less time (and possibly less fertilizer) than direct seeding (up to 2 years for a full cover), may justify the higher price of sod. If sod is used, this study showed that hard fescue establishment is more rapidly accomplished when sod is harvested at 1.5 inches thickness than at 0.75 inch, and fertilized with at least $1 \mathrm{lb} / 1000$ $\mathrm{ft}^{2}$ of nitrogen applied topically after sod is laid.

\section{Literature cited}

Beard, J.B. 1973. Turfgrass: Science and culture. Prentice-Hall, Englewood Cliffs, N.J.

Hafenrichter, A.L., J.L. Schwendiman, H.L. Harris, R.S. MacLauchlan, and H.W. Miller. 1979. Grasses and legumes for soil conservation in the Pacific Northwest and Great Basin states. Soil Conserv. Serv. U.S. Dept. Agr. Agr. Hdbk. 339.

Harivandi, M.A. and C.L. Elmore. 1990. Hard fescue-Characteristics and herbicide tolerance. California turfgrass culture. vol. 40. Nos. 1-4. p. 5-6.

Harivandi, M.A. and L. Wu. 1990. Fine-leaf fescue performance for California Central Coast. California turfgrass culture. vol. 40 . Nos. 1-4. p. 7-8.

Hitchcock, A.S. 1935. Manual of the grasses of the United States. U.S. Dept. Agr. Misc. Publ. 200.

Thornburg, A.A. 1982. Plant material for use on surface-mined lands in arid and semiarid regions. U.S. Dept. Agr.Soil Conserv. Serv. TP-157 (EPA - 600/7-79-134). 